\title{
The Fading Value of Tolerance "Andhap Asor", Among Millennial Generation in Surakarta
}

\author{
Luhur Budi Sayekti ${ }^{1}$, Triana Rejekiningsih ${ }^{2}$, Rini Triastuti ${ }^{3}$ \\ ${ }^{1}$ Luhur Budi Sayekti, Sebelas Maret University, Indonesia. \\ ${ }^{2}$ Triana Rejekiningsih, Sebelas Maret University, Indonesia. \\ ${ }^{3}$ Rini Triastuti, Sebelas Maret University, Indonesia. \\ *Corresponding author.Email:luhurbs028@student.uns.ac.id
}

\begin{abstract}
The cultural wealth is a gift that is owned by Indonesia to make diversity a priority in Indonesia. Surakarta City is one area that is closely related to local culture and values that are integrated into the life of its people. The city, which is inhabited by various cultures and ethnicities, makes local values develop well, mutual respect and mutual respect for other ethnicities is an added value for the people of Surakarta. This respect and respect make the people of Surakarta a tolerant society or understands tolerance. The purpose of this study is to dig deeper into the values possessed by the people of Surakarta in maintaining harmony in everyday life, especially in terms of tolerance in the millennial generation. The value of "Andhap Asor" is an important component of maintaining tolerance in Surakarta. The author highlights the value of Andhap Asor in the lives of the people of Surakarta with a qualitative method with data triangulation to deepen the value of Andhap Asor applied by the Surakarta community. The millennial generation is an indicator of the local community's sociocultural value that is still inherited or rejected by the next generation. This rejection is not without reason. Globalization is the main factor why our local values can be marginalized. Millennials are more likely to accept globalization and the culture it brings. The value of Andhap Asor, which has become one of the advantages of Surakarta society as a tolerant society, has begun to be abandoned with the individualistic, anti-social, and closed nature of the millennial generation. The challenge faced by the people of Surakarta is a common challenge in preserving local values, which are the advantages of the Indonesian nation towards a developed society with diversity in accordance with the concept of Bhineka Tunggal Ika.
\end{abstract}

Keywords: tolerance, the millennial generation, Andhap Asor, Surakarta society

\section{INTRODUCTION}

The city of Surakarta, with its various cultures, makes a country that is diverse and accepts diversity. Many ethnic groups and ethnicities who live in Surakarta create local values related to tolerance, which is generally known to develop in Indonesia. Tolerance is a virtue that develops in society to maintain harmony between ethnic groups, cultures, ethnicities, and other diversity that exists around the community. Tolerance in the artist's language is adapted from the Latin "tolerantia" which means looseness, gentleness, and patience. [1] . According to $\mathrm{KBBI}$ [2] tolerance comes from the word tolerance, which means a tolerant character or attitude (respect, and allow), which is different and contrary to its position. Tolerance leads to attitudes that develop in individuals that have an impact on their social. An open, voluntary, humble, and gentle attitude. Different views, incompatible perceptions, and different attitudes and lifestyles will greatly influence society's harmony. 
Tolerance is not a strange thing for the people's of Surakarta. The cultural culture that develops in the city of Surakarta is so diverse. Lickona [3] said that character is related to the concept of character (knowing character), character attitude (character feeling), and character behavior (character behavior). This habit can be interpreted as a hereditary inheritance passed from generation to generation. Culture is very thick with Surakarta because it has one of the kingdoms centered in Mangkunegaran, administratively located in Pasar Kliwon Sub-District. Another culture that also developed was the Chinese and Arab ethnic cultures, which had long lived in Surakarta as traders in the Pasar kliwon sub district. There is another side of Surakarta as the city of choice for overseas after Yogyakarta. Many of these overseas are job seekers and students who continue their education in Surakarta. Tolerance is part of developing ethics and character in society. Tolerance is the act, and the rules governing tolerance are the law. Said by M. Said [4] that Ethics and Character are the same existence but different in meaning. Character is more used to judge the good and bad of action, while ethics is a code or character control system.

Various kinds of ethnic and cultural backgrounds from various regions united in the city of Surakarta make it a multicultural plural city. The people of Surakarta's pluralism is supported by the development of education and the community's mindset that always maintains harmony in daily life. The noble attitude developed by the people of Surakarta's people supports maintaining the community's condition, which supports the development of an attitude of tolerance among plural and pluralistic communities. Noble values in culture and tolerance are crucial components in maintaining harmony in the life of a plural community with various backgrounds.

The millennial generation, as the new generation of the Indonesian nation has cultural and ethical references influenced by technological developments and globalization. the values and ethics that enter from outside cultures are adapted by the millennial generation and the values and ethics that live around them as genuine products of a developing society's habits. Generations that change every time follow the generation theory put forward by Strauss and Howe [5], where several levels of generation include traditionalists, baby boomers, generations $\mathrm{X}$, $\mathrm{Y}, \mathrm{Z}$, and Alpha. This millennial generation is the $\mathrm{Z}$ generation when referring to Strauss and Howe's theory. Living with technological advances that receive various kinds of information and live in a very pluralistic society, such as in the city of Surakarta. The life they lead has a big impact on their daily habits. Understanding the people themselves' ethical values and the different global societies sometimes make them choices about values or ethics to adapt to life. The perception of the millennial generation that prefers foreign cultures to become their daily habits is a problem for preserving the original ethical values of Javanese culture. The original values that display the original Javanese personality passed down from generation to generation seem to have faded due to the millennial generation choosing ethical values that come from the global community.

The millennial generation's perception has become a serious problem, especially in the development of generational characters. The ethical values that develop with the local community will be inferior to the global community's ethical values that do not match the Javanese personality. For example, there is a subtle language in the regional language in Javanese custom intended for us to talk to older people, have a higher degree, and respect foreigners. Millennials prefer to use Indonesian to speak to anyone. It is not wrong to use the national language for daily conversation. However, this becomes a problem if we maintain the local community's personality who must use the local language. The problems above illustrate that the millennial generation does need special attention to maintain the local culture, especially the people of Surakarta. 


\section{METHOD}

The study method is important to determine how the collected data is collected according to the needs of the analysis. Methods that impact on collecting some valid data and support this research completion. The method used to collect data about Andhap Asor as a cultural heritage value, especially the Javanese tribe, is the triangulation method, where data is collected through observation, questionnaires, and search for related documents. This observation is carried out in the community in general, considering that the study's target is the millennial generation with vulnerable ages ranging from 18 years to 25 years. The questionnaire is used as additional data to be disseminated to the community or youth community so that a more comprehensive age range is used and searches for related documents on various matters related to politeness, tolerance, and respect.

Some of the indicators that appear to obtain data regarding the values and values of Andhap Asor include 1. Acceptance of strangers / not yet known 2. Behavioral actions towards the interlocutor who is under or overage. 3. Positioning oneself towards heterogeneous situations in society. 4. Developing a tolerant attitude towards youth in a multicultural society. The purpose of this study is to find differences in perceptions or shifts in the value of national culture within the millennial generation in the city of Surakarta

\section{RESULTS AND DISCUSSION}

\subsection{Andhap Asor Concept Born in Javanese Culture}

A culture that develops in a place will produce several forms of cultural results. The results of this culture can be seen physically as well as local cultural habits. Soekanto [6] says that culture owned by a nation or society has small elements that actually become a unity, which is Physical unity, we can see in art, wood carving, traditional clothes, and others, while for customs it creates norms that regulate people's lives. These values are extracted from generation to generation habits and experiences to become a standard adhered to by the community. This value is felt to be a suitable Javanese culture As for life together and keep them from being wrong. Javanese culture, as a large culture that has developed in the country of Indonesia, has a very thick cultural essence and values from across generations. Javanese culture is known to the Indonesian people as a culture that is gentle and full of beauty. His art, which carries many flexibility and gentle movement themes, also influences the perception or philosophy that develops in Javanese society. A soft culture forms Javanese society's personalities to be friendly, awkward towards new people, and puts others ahead of themselves. Surakarta society is thick with culture and slowly creates caste or ranks in the community. Making Franz Magnis Suseno [7] differentiates Javanese society into three social groups, namely: 1. little people or small people, are people who mostly work as farmers 2. Priyayi people, employees, or intellectuals 3. Nobles, although small but get high prestige. This grouping provides a portion of Javanese ethics or "Unggah-Ungguh" use. Between 1 caste with a higher caste, the use of "Unggah-Ungguh" is also different. The higher the relationship, the "UnggahUngguh" used must also be more polite.

\subsection{The existence of Andhap Asor Values in Surakarta}

Moral values and character will emerge as the community develops in an area. The society whose interactions are so complex makes the development of a habit in society even faster. People who are thick with culture and aesthetic values live as humans who cannot rely on themselves in life. Interaction fosters a value in which this value is agreed upon by the community, regulating their side of the interaction. Good things and bad things and their consequences are listed in the customary values of society. Until now, this crystallized value has been the guideline for 
society in assessing the behavior of existing individuals or groups. Character values and ethics are the relationships between human thought and activities. According to Franz Magnis Suseno [8] ethics is a science that ends in orientation. Humans consciously try to use their intellect and thinking power to deal with a problem and how they should look at life to be better. Ethics and Character grow together with culture. The more thick the culture is, the culture will affect the development of ethics and character. High thinking and power in accordance with cultural development results in high ethics and character.

As a cultural city that is thick with its culture and arts, the city of Surakarta has a strong side informing its ethical values. As part of people's lives, Javanese culture is very thick and is like an inseparable side of Surakarta society. A distant relative from Yogyakarta as a cultural city close to its Javanese culture gives the impression that the values that have developed until now are kept from generation to generation. The values that grow in Javanese culture are very diverse, especially in the city of Surakarta. People of Surakarta's personality are implemented in the form of values such as Tepa Slira, Lembah Manah, Andhap Ashor, Grapyak Semanak, and Gotong Royong, Guyub Rukun, Ewuh Pekewuh, and Pangerten. All these growing values symbolize the goodness in the behavior of the people of Surakarta. One of the values that make Surakarta society attractive is Andhap Asor. Etymologically, Andhap Asor is divided into two words in Javanese, namely andhap and asor. In Indonesian, it can be interpreted as andhap: humility and Asor: heart, or in the Indonesian concept, it is called humble.

The ethical values that are so many in Surakarta society make millennials or the current generation less understanding of the Javanese tribe's original ethical values. Respondents of $46.54 \%$ have a rare view of using ethical values or uploading in Javanese culture and their use in daily life, $34.46 \%$ stated that they often use ethical values or "Unggah-Ungguh" in Javanese culture on The rest of daily life, $12.04 \%$ do not know about Javanese "Unggah-Ungguh" culture, and $6.96 \%$ do not know about "Unggah-Ungguh" in Javanese culture from a total of 35 respondents who filled out the questionnaire. They see that their interlocutors only use Indonesian or even use local languages only impolitely in everyday life, especially when talking to younger ones. There are 3. Ngoko, Kromo Inggil, and Kromo Alus. The younger correspondents who spoke to them mostly used ngoko alus language, which tended not to represent politeness.

\subsection{Andhap Asor in Pluralism and Multiculturalism}

According to a survey conducted by the Setara Institute [9], Surakarta is one of the most tolerant cities. The components of society, composed of 3 major ethnicities, namely Javanese, Chinese, and Arabic. Make Surakarta society a plural city. The concept of pluralism is more incorporated into multiculturalism due to the fusion of cultures and the coexistence of ethnic or ethnic cultures living together as "cherishing and encouraging more than one cultural approach, incorporating more than one cultural approach into the majority system of belief and practice, and respecting the cultural demands of all or more than one of the nation-state's communities, " Parekh [10]. One of the other factors Surakarta's city as a city of education and the economic turn around in Central Java and its surroundings. It made many overseas people come to study as students or students or try their luck to find a fortune in Surakarta. The city of Surakarta, which is transformed into as multicultural or pluralism city, is an important step in a tolerance aligned with a culture that must be preserved. Tolerance is needed to build a heterogeneous society consisting of various ethnicities, religions, ethnicities, and groups. Andhap Asor as a philosophy or behavior guide for Javanese society is in line with the concept of tolerance itself. 
Humble behavior greatly interprets Andhap Asor in Javanese culture, according to Dwi Santoso [11] that adhap asor or "Lembah manah" as a model or position of a person in a humble state. A person views other human beings as not being noble or more than others.

A very dense society makes intense interactions possible. We will meet people we have never met, meet people with high charisma, or meet people who are older than us. We who meet strangers must be the first thing we do is try to behave politely and politely in front of that person. Our process of behaving politely and politely when we enter into understanding Javanese culture has entered into Andhap Asor. What is more, if we meet fellow tribes, but we just do not know it, besides being polite, we can use Javanese Krama Alus as much as possible to interact verbally.

\subsection{Millennial Generation's Perception of Andhap Asor in Local Ethical Values}

As a generation whose development is not far from technology and scientific progress and changes in society, the millennial generation will see an ethical value that develops and is inherited from a different point of view. Thomas Lickona [12] said that character education is a conscious effort to obtain virtue, objectively good human quality, not only good for individuals but also society. Their mindset has entered into the mindset of a global society that removes barriers to culture and values. They consider culture sustainable if it is in accordance with themselves society is the development today. They will reject the original culture or absorption from outside if the culture is not practical for them.

These changing perceptions have influenced how the millennial generation behaves in society. According to Franz Magnis Suseno [13] Javanese culture can be said to be drowned by the waves of modernization. The generations can felt this change before them. Many millennials behave not in accordance with the norms and ethical principles that develop in society. Lifestyle, how to dress to how they communicate with other people. The millennial generation tends to have an individualistic, anti-social, and closed attitude. The concept of Andhap Asor that develops in Javanese society puts forward how we can respect people and feel that we are not necessarily better than our interlocutors. They are starting to be rejected with their lifestyle, which is in stark contrast to the values contained in Andhap Asor. The concept of humanized life has ethics and etiquette as its guide. M Suprihadi [14] People accustomed to etiquette desire to achieve an ethical life, which can be viewed as ethically acceptable. Millennials try to adopt the culture that comes rather than preserving their own culture. Language, manners, and politeness towards elders are in the spotlight because they do not reflect the original Javanese personality, which is thick with tolerance values, one of which is Andhap Asor.

\section{CONCLUSION}

Tolerance and an ethic that develop in a developing society are two things that complement and influence each other. Tolerance is a universal notion understood by the global community that affects their lives' ethics and character. In particular, the ethics that develop in the local community is a representation of local tolerance. Andhap Asor is one of the ethics and characters developed in the Surakarta society or Javanese ethnicity, which was exclusively developed. In general, “Andhap Asor” is the behavior or "Unggah-Ungguh" that Javanese people do in respect of others' respect. Andhap Asor, which is a value that has been preserved by the Javanese people from generation to generation, is now being abandoned by the community, especially the millennial generation. Tolerance and especially Andhap Asor have the same obstacles in its application in society, especially when education on tolerance and values of Andhap Asor is carried out to the millennial generation in Surakarta, particularly in Indonesia. Several factors that influence are 1. The 
character of the community. 2. Society accepts a change due to globalization 3. Cultural inheritance with character values cannot be maximized 4 . Character education in the next generation is lacking. Changes that occur because many millennial generations prefer values or characters that come from outside cultures must make the community, policymakers, or educated people make innovations that can answer challenges in order to continue to preserve Andhap Asor as a part of tolerance that is native to the Surakarta area, so that remains in ugemi or be used as a role model for the millennial generation is behaving in real society or society in cyberspace.

\section{ACKNOWLEDGMENT}

Special thanks to the research team PNPB 2020 for the insightful disccusions during conduct this research and we would also like to thank all participants of this reseach who give us their times to complete this research. This research was supported by LPPM UNS.

\section{REFERENCES}

[1] Hornby AS, 1995, Oxford Advanced Learner's Dictio Oxford: University Printing House, , p. 67)).

[2] Kementerian Pendidikan dan Kebudayaan. 2016. Kamus Besar Bahasa Indonesia (Edisi Kelima). Jakarta: Badan Pengembangan dan Pembinaan Bahasa, P. 1477-1478),

[3] Thomas Lickona, 1991, Educating for Character: How Our School Can Teach Respect and Responsibility, (New York, Toronto, London, Sydney, Aucland: Bantam books, p.15.

[4] M. Said, 1976 Etika Masyarakat Indonesia (Jakarta : Pradya Pramita, p. 23.

[5] Strauss, William dan Neil Howe. 1991. Generations: The History of America's Future, 1584 to 2069. William Morrow \& Co.

[6] Soekanto, S. (2003). Sosiologi Suatu Pengantar. Jakarta: Rajawali Pers , p. 175.
[7] Franz Magnis Suseno dan S. Reksosusilo C.M ., Etika Jawa Dalam Tantangan Sebuah Bunga Rampai, (Yogyakarta : Kanisius, 1984, p.11.

[8] Franz Magnis- Suseno. 2003. Etika Jawa (Sebuah Analisa Falsafi tentang Kebijaksanaan Hidup Jawa), Yogyakarta : PT Gramedia Pustaka Utama. P.17.

[9] SETARA Insitute dan Unit Kerja PresidenPembinaan Ideologi Pancasila, 2017. INDEKS KOTA TOLERAN (IKT) TAHUN 2017.

https://setara-institute.org/indeks-kota-tolerantahun-2017/'

[10] Parekh, Bikhu. 1998. A Commitment to Cultural Pluralism. Paper presentented in Intergovermental Conference on Cultural Policiesn for Development, Stickholm, Sweden, 30 March - 2 April 1998. Diakses melalui laman http://unesdoc.unesco.org/images/0011/0

01107/110756Eo.pdf. Diakses pada tanggal 12 September 2020.

[11] Dwi Santoso, The Realisation of Andhap Asor 'Modest' and Ngajeni 'respect' in the Meeting of Yogyakarta's Provincial Parliament, International Journal on Studies in English Language and Literature (IJSELL) Volume 4, Issue 9, September 2016, PP 58-64.

https://www.arcjournals.org/pdfs/ijsell/v4-i9/8.pdf

[12] Thomas Lickona, Character Matters: Persoalan Karakter, terj. Juma Wadu Wamaungu \& Jean Antunes Rudolf Zien dan Editor Uyu Wahyuddin dan Suryani, (Jakarta: Bumi Aksara, 2012 p. 05.

[13] Franz Magnis Suseno, Etika Dasar MasalahMasalah Pokok Filsafat Yogyakarta: Kanisius, 2003 p. 01.

[14] M. Suprihadi Sastrosupono, Etika dan Kepribadian (Semarang: Satya Wacana, 1979. p.06. 